\title{
Influence of Human Resource Management Practices on Competitive Advantage through Operational Excellence: Case study on SME Food and Beverages In Bandung Regency West Java Indonesia
}

\author{
Andri Irawan ${ }^{1}$, Eka Ludiya ${ }^{2}$, Mochamad Vrans Romi ${ }^{3}$, Rahardianto ${ }^{4}$ \\ \{andri.irawan@lecture.unjani.ac.id ${ }^{1}$, eka.ludiya@lecture.unjani.ac.id ${ }^{2}$, vransromi@gmail.com ${ }^{3}$, \\ rahardianto82@yahoo.co.id $\left.{ }^{4}\right\}$ \\ 1,2,3,4 Universitas Jenderal Achmad Yani, Jl. Terusan Jenderal Sudirman Cimahi, Jawa Barat Indonesia \\ Telp. 6656611, Indonesia
}

\begin{abstract}
Competitive advantage is a desired outcome and expected by the SME actors food and beverages to win the tougher competition in Bandung district where the food and beverage SME sector is growing rapidly. One of the causes that influence the competitive advantage is the practice of human resources management and the operational excellence of human resources management practices and operational excellence can be made capital for business actors To acquire a competitive advantage of SME food and beverage. The results of research that has been done using samples of 100 perpetrators of SMES food and beverage using aksidental sampling method concluded that the respondents ' perception of human resource management practices and competitive advantage Shows important criteria while operational excellence shows criteria very important while human resource management practices give greater influence to competitive advantage if through operational excellence.
\end{abstract}

Keywords: human resource management practices, competitive advantage, operational excellence

\section{Introduction}

One of the industries that are the scope of SMES in Indonesia is the food and beverage industry and included in the processing industry. Food and beverage industry has a huge opportunity because even in urban areas $53 \%$ higher expenditure is used for non-food commodities whereas in rural 59\% higher expenditure on food will but according to [1] major proportions of production are most highly used for consuming food and beverages so whereas for in rural areas the primary proportion of production is highest used for long lasting commodities.

Currently the current industrial Revolution of 4.0 is taking place this has a huge impact to SMES. The 4.0 industry also has challenges that must be faced ahead, such as business paradigm change issues, security, safeguards, legal and IP issues, standardization and human resource planning challenges. The worst mistake in dealing with this change is the inability to take the role of the change itself, because the future of the 4.0 industry is still unclear, its success and failure depend heavily on the involvement of all Stakeholders. [2] 
This means that it will give a huge impact or change in the area of operations management such as the flexibility of production, increased trend of production speed, higher product quality, lower average failure Product and human resource management such as the improvement of work life. In addition to carrying impact or consequences, the 4.0 Industrial Revolution also resulted in the emergence of challenges such as in operations management such as the issue of change paradigm of business and the need for standardization of products and processes while in Human resource management is facing the challenges of human resource planning. The company if not anticipating any such changes will cause the company will be difficult to compete in the future.

Bandung Regency is one of Regencies in West Java province with a total area of 1762 , $40 \mathrm{Km} 2$, then the average population density of Bandung regency as much as 2,041 inhabitants per $\mathrm{Km} 2$. The population of Bandung regency is quite large is a very valuable workforce potential especially when the quality of its human resources is well managed. The working age population in Bandung District reaches 2,379,411 personnel absorption of manpower in the processing industry sector is $33.8 \%$ [3].

Number of SMES growth according to Renstra 2016-2021 [4] Increased. The growth of SMES from 2010 to 2015 reached the total number of SMES from 2010 up to 2015 reaching 9,615 MSMES from the target set 9,236 SMES.

Operational excellence is an implementation of a consistent and reliable business strategy in a competition or competition. [5]. The change in business environment has brought a little impact to the company. SDM has also undergone a change from a partial to a more integrated and strategic way. [6]. The company in running its business strives to form a competitive advantage in winning competition. The results of a descriptive study conducted by [7] shows that resources, knowledge sharing, strategy implementation and competitive advantage are still not optimal.

Based on the explanation above, the central issue of my research is the practice of human resource management of competitive advantage through operational excellence in SMES Food and beverage in Bandung Regency

\section{Literature Review}

Practice Human Resource Management

Some key issues currently related to human resources causes the company to repositioning HR functions among others (Schuller, 1990) dalam [6] Is:

1. Manage human resources to create human resources (competence).

2. Manage workforce diversity to achieve competitive advantage.

3. Manage human resources to improve competitiveness or competitiveness.

4. To dodge human resources to face globalization (go International).

(Pfeffer, 1995) in [6] Successful competing organizations can be achieved with the management of potential human resources it owns. SDM can be used as a source of good competitive advantage and not easily imitated competitors because:

1. The successful competition gained from HR management effectively is not as transparent as managing other human resources, such as looking at computerized information systems consisting of semi conductors and a number of control machines.

2. How HR is managed influenced by culture. The organizational culture affects the skills, human resources, and their appropriateness with the existing system. 
Next Pfeffer (1995) in [6] Emphasise that a competitive advantage can be achieved through effective management of the company's human resources. While [8] In his research concluded that the most important factor in human resource practice is the sociocultural and institutional factors. The Human resource management practice indicators used in this study were socioultural and institutional factors.

\subsection{Competitive Advantage}

Competitive advantage has become a necessity for SMES to avoid the very strict competition. [9] In his research concluded to achieve a competitive advantage among competitors, SMES must use an "aggressive" strategy that is by reducing costs, creating new products, quality improvements, market expansion.

[10] In his research argues that competitive advantage must be maintained, and developed, one of them by always innovating, because of the nature of humans who love new things and the state of the world where competition is increasingly complex and Sharp, there will be many strong competitors that will come, strive and the possibility of successfully seize the market that has been owned.

The competitive advantage indicator used in this research is to create new business plan, gain additional capital, labor insurance, improve and improve product quality, improved service quality and promotion intensity.

\subsection{Operational Excellence}

Excellence is defined as a combination of operational excellence (efficiency) and service Excellence (effectiveness). Further analysis guarantees that the existing business advantage model can harm maintaining excellence and make good business. [11].

[12] Concluded in his research in Jordania that operational excellence is simultaneously influenced by the operation strategy, leadership and practice of human resource management, where the operating strategy has the highest influence and Leadership gives the lowest influence. Operational Excellence According to [13] s a consequence of the company's practice broadly based on the correct principles that can be classified in four dimensions; Progress, corporate alignment and results. To achieve operational excellence, organisations must achieve a high level of maturity and measurable success in four dimensions externally assessed by accredited agencies or consultants. [14] $\mathrm{n}$ his research concluded that the contortions of operational excellence among all definitions as well as indicators were continuous improvement, cost reduction, quality, time utilization, operational efficiency, staff involvement and optimization of output. 


\section{Research methods}

This type of research is used to examine causal relationships. The sampling method used by researchers is a sampling nonprobability by means of aksidental sampling [15]. The analysis tool to be used in this research is SEM Pls with the following models:

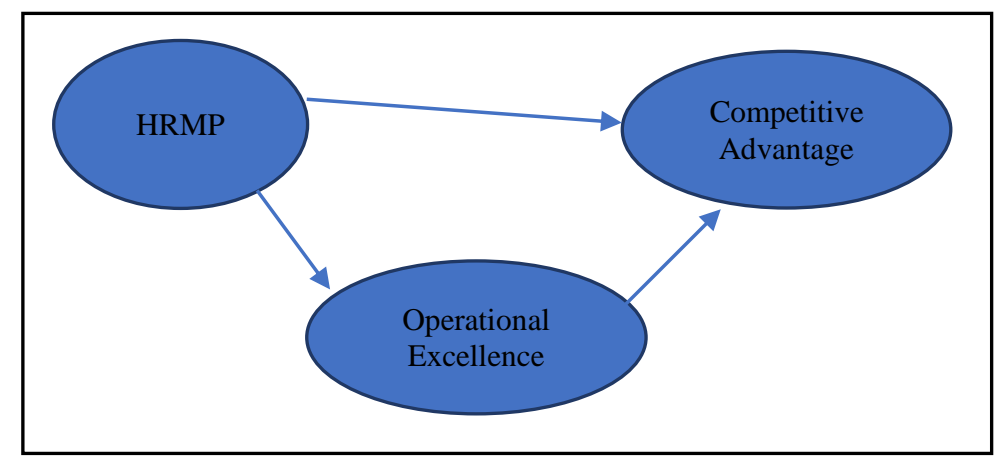

Fig. 1. Research Model

\section{Results and discussion}

The respondent's response to the statement regarding the research variable can be seen in the table below:

Table 1. Respondent's response to research variables

\begin{tabular}{|c|l|c|}
\hline No & \multicolumn{1}{|c|}{ Variable } & Criteria \\
\hline 1 & Human Resource Management Practice & Important \\
\hline 2 & Competitive Advantage & Important \\
\hline 3 & Operational Excellence & Very Important \\
\hline
\end{tabular}

Source : Data processed, 2019

Further to know the outcome of the influence of human resource management practices on competitive advantage through operational excellence can be seen in the image below: 


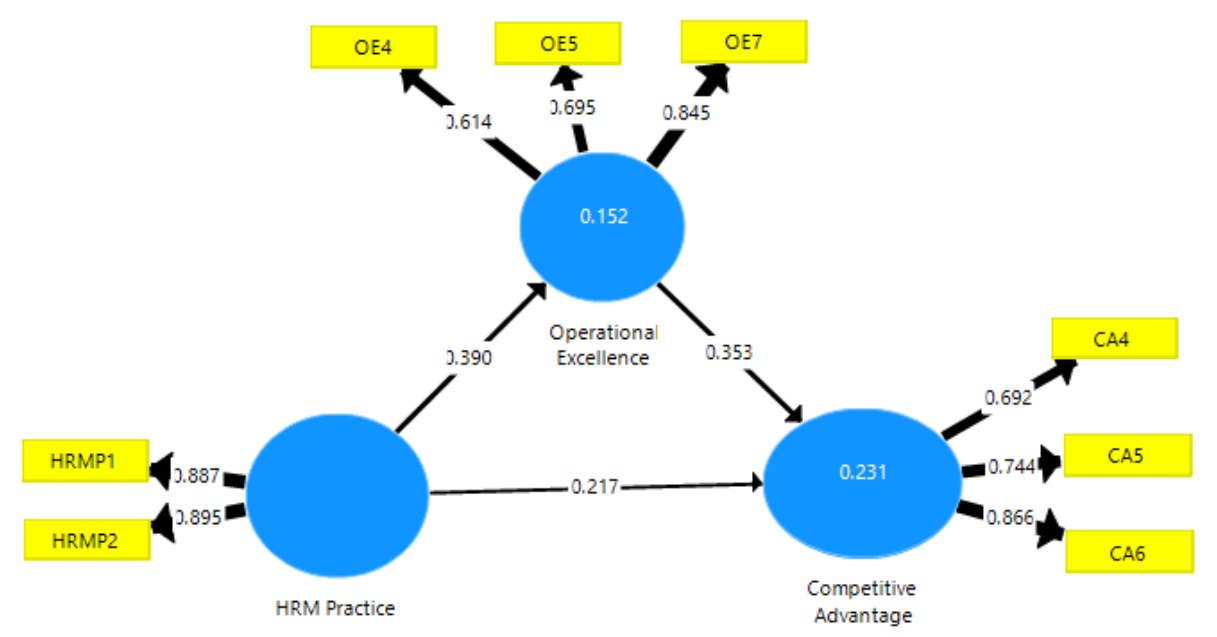

Fig. 2. Influence of human resource management practices on competitive advantage through operational excellence in SME Food and beverage in Bandung Regency

Based on the image above the correlation coefficient of HRM practice variable to operational excellence of 0.390 it shows that the relationship between HRM practice of operational excellence belongs to the category enough. While the value of coefficient of correlation between operational excellence to a competitive advantage of 0.353 it shows that the relationship between operational excellence to competitive advantage is included in the strong category. Furthermore the value of correlation coefficient of HRM practice to a competitive advantage of 0.217 it shows that the relationship between HRM practice to competitive advantage belongs to low category.

Furthermore, the influence of HRM practice on operational excellence is $15.21 \%$ while the influence of operational excellence on competitive advantage is $12.46 \%$. So the total effect of HRM practice on competitive advantage through operational excellence is $37.67 \%$. Furthermore, the influence of HRM practice on competitive advantage is $4.71 \%$.

\section{Conclusion}

Based on the results and discussion that has been done, the average response of respondents ' perception of human resource management practices and competitive advantage belongs to the important category while operational excellence includes Categories are very important. While based on the results of calculations using SEM Pls can be concluded that the practice of human resource management gives a direct effect of $4.71 \%$ against competitive advantage but the practice of human resources management Will influence the competitive advantage through operational excellence of $37.67 \%$ in the food and beverage SMES in Bandung West Java regency of Indonesia.

Acknowledgments. The author would like to thank you for Rector Unjani Mr. Witjaksono, MSc, NSS ,; Chairman of LPPM Unjani Ibu Dr. Anceu Muniarti, SSi, MSi, and the Dean of 
the Faculty of Economics and Business, Dr. Elis Dwiana Ratnamurni, SE, MP who has provided financial support for this research.

\section{Reference}

[1] Badan Pusat Statistik, "Statistik Indonesia dalam Infografis," 2018.

[2] R. Fauzan, "Karakteristik Model dan Analisa Peluang-Tantangan Industri 4.0," J. PHASTI., vol. 04, April, no. April, pp. 1-11, 2018.

[3] BPS Kabupaten Bandung, "Kabupaten Bandung dalam Angka 2017,” 2017.

[4] Dinas Koperasi dan UKM Kabupaten Bandung, "Rencana Strategis (Renstra) Tahun 2016 - 2021," no. 022, 2016.

[5] C. Seifert, Achieving Operational Excellence in the Face of Complexity. London: Wilson Perumal \& Company; Ltd, 2013.

[6] L. Ellitan, "Praktik-Praktik Pengelolaan Sumber Daya Manusia Dan Keunggulan Kompetitif Berkelanjutan,” J. Manaj. dan Kewirausahaan, vol. 4, no. 2, pp. 65-76, 2002.

[7] Otong Karyono, "Kajian Faktor Determinan Dalam Membangun Keunggulan Bersaing Melalui Implementasi Strategi Pada Usaha Kecil Dan Menengah,” in Proceeding STIMA 2.0, 2016, vol. 91, pp. 316-31.

[8] A. Al Ariss and Y. Sidani, "Comparative international human resource management: Future research directions," Hum. Resour. Manag. Rev., vol. 26, no. 4, pp. 352-358, 2016.

[9] I. Y. Niode, "Analisis Strategi Keunggulan Bersaing (Competitive Advantage) Sektor Usaha Kecil Menengah di Kota Gorontalo (Studi Industri Meubel di Kota Gorontalo)," J. Bisnis dan Manaj., vol. 4, no. 2, pp. 91-101, 2012.

[10] A. Setyawati, "Keunggulan Kompetitif dan Inovasi (Studi pada UMKM Sektor Industri Makanan dan Minuman di Bandung Raya)," Akademika, vol. 13, no. 2, pp. 41-44, 2015.

[11] M. Thürer et al., "On the meaning and use of excellence in the operations literature : a systematic review," Total Qual. Manag., vol. 0, no. 0, pp. 1-28, 2018.

[12] R. M. Shehadeh, Z. M. F. Al-Zu'bi, A. B. Abdallah, and M. Maqableh, "Investigating Critical Factors Affecting the Operational Excellence of Service Firms in Jordan," J. Manag. Res., vol. 8, no. 1, p. 157, 2016.

[13] S. J. Rusev and K. Salonitis, "Operational Excellence Assessment Framework for Manufacturing Companies," Procedia CIRP, vol. 55, pp. 272-277, 2016.

[14] M. H. Muazu and R. Tasmin, "Operational Excellence in Manufacturing, Service and the Oil \& Gas: the Sectorial Definitional Constructs and Risk Management Implication, " Traektoriâ Nauk. = Path Sci., vol. 3, no. 9, 2017.

[15] Sugiyono, Metode Penelitian Bisnis (Pendekatan Kuantitatif, Kualitatif dan R n D). Bandung: Alfabeta, 2015. 